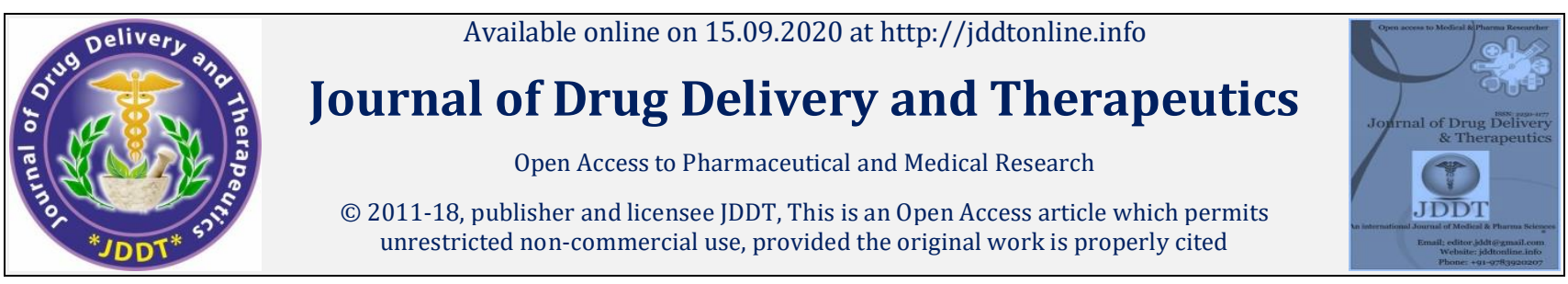

Open Access

Research Article

\title{
Study of the physico-chemical quality of Curcuma longa (powder and rhizome) marketed in the town of Sétif
}

\author{
Tedjari N.*1, Douadi N. ${ }^{2}$ \\ ${ }^{1}$ Department of Vegetal Biology and Ecology, Faculty of Nature and Life Sciences . Ferhat Abbas University Setif-1. 19000 Setif, Algeria \\ ${ }^{2}$ INSEP national institute specialized in vocational training hadadi chérif) el Hidhab Sétif, Algeria
}

\begin{abstract}
Over the past two to three decades, renewed interest has been shown in the Curcuma longa plant because of the multiple properties attributed to its spice, properties that are traditionally recognized or empirically observed over hundreds of years of use. Curcuma longa is a herbaceous plant belonging to the Zingiberaceae family, cultivated in India and Southeast Asia and considered a coloring spice. Turmeric, especially its rhizome (the underground part), has been used not only as a food spice, but also as a medicinal plant since time immemorial in China and India. The recognition of its medicinal properties is therefore recent in the West. The history of Curcuma is also being written in the future, as much scientific research is being carried out, particularly on the effects of one of its main components, curcuma, in the prevention and treatment of certain cancers. It is in this context that the aim of this work is to evaluate certain parameters of the physicochemical quality of this plant, such as the level of impurity, ash content, moisture content, soluble and insoluble ashes in water, coloring power and chromatography on thin layers on the basis of the standards dictated by the French official journal (JORF).This study was carried out on the two rhizome and powder forms of Curcuma longa marketed. For this, five spice shops (2 samples / shop) were selected at random in the town of Sétif. Analyses of the samples taken were carried out with the collaboration of two laboratories: one INSFP (National Institute for Specialized Professional Training Hadadi Cherif el Hidhab Setif) and the other ERIAD (Riad Setif). The results obtained vary from one type to another and from one store to another. The analysis of the variance of impurity levels, moisture content, acid insoluble ash and TLC is significant whereas it is not for other parameters such as: total ash, water insoluble ash and colouring power.
\end{abstract}

Keywords: Curcuma longa, Rhizome and powder, city of Sétif, Physicochemical parameters, TLC.

Article Info: Received 17 July 2020; Review Completed 22 Aug 2020; Accepted 30 August 2020; Available online 15 September 2020

Cite this article as:

Tedjari N, Douadi N, Study of the physico-chemical quality of Curcuma longa (powder and rhizome) marketed in the town of Sétif, Journal of Drug Delivery and Therapeutics. 2020; 10(5):131-142 http://dx.doi.org/10.22270/jddt.v10i5.4294

*Address for Correspondence:

Tedjari N., Department of Vegetal Biology and Ecology, Faculty of Nature and Life Sciences. Ferhat Abbas University Setif-1. 19000 Setif, Algeria

\section{INTRODUCTION}

The use of plants in herbal medicine is very old and is currently experiencing renewed public interest, according to the World Health Organization (WHO) (2003), about 65-80\% of the world's population uses traditional medicine to meet their primary health care needs, due to poverty and lack of access to modern medicine $\mathbf{1}$. Due to their chemical composition, medicinal plants are of considerable economic interest as part of the food, pharmaceutical and cosmetic industries ${ }^{2}$. Spices are classified as aromatic plants and are part of medicinal plants. Indeed, they are endowed not only with perfumed and culinary qualities, but also with varied medicinal virtues thanks to the various active ingredients they contain 4 .

Turmeric (Curcuma longa) is a herbaceous plant belonging to the family Zingiberaceae, it is a spice widely used in Asian cuisine generally and Indian essentially. This spice is characterized by its yellow color which comes from a mixture of phenolic pigments, the curcuminoids which are natural antioxidants 9.133 species have been identified throughout the world, among them Curcuma amada, Curcuma angustfolia, Curcuma aromatica, the most important of which is Curcuma longa L., the most widely used species today, not only as a food spice, but also as a medicinal plant since time immemorial in China and India. The recognition of its medicinal properties is therefore recent in the West. The history of turmeric is also being written in the future, as much scientific research is being carried out, particularly on the effects of one of its main components, curcuma, in the prevention and treatment of certain cancers. One of the main problems of the food industry is to ensure good food preservation. In particular, oxidation phenomena are feared. Indeed, at the lipid level, oxidative degradation leads to a loss of vitamins, a decrease 
in nutritional value, a deterioration of taste and sometimes even the appearance of toxic substances 11,12

The microbiological quality of a food is one of the essential bases for its ability to satisfy consumer safety. A food, exposed to deterioration by bacteria and moulds can reduce its sensory, nutritional and health characteristics 6, 14 Despite improvements in food preservation techniques, the nature of food preservatives remains one of the most important public health issues $\mathbf{3 , 5 , 8}$. Our study aims to show the importance of spices in preserving their sanitary quality (healthiness and safety) through the physicochemical properties of the two culinary parts rhizome and powder widely used Curcuma longa sold in the markets of the wilaya Sétif (Algeria).

\section{MATERIALS AND METHODS}

Our work consists in evaluating the physico-chemical quality parameters of the spice of the genus Curcuma longa in its two powder and rhizome forms (Fig.01 and 02) marketed at the level in the town of Sétif.

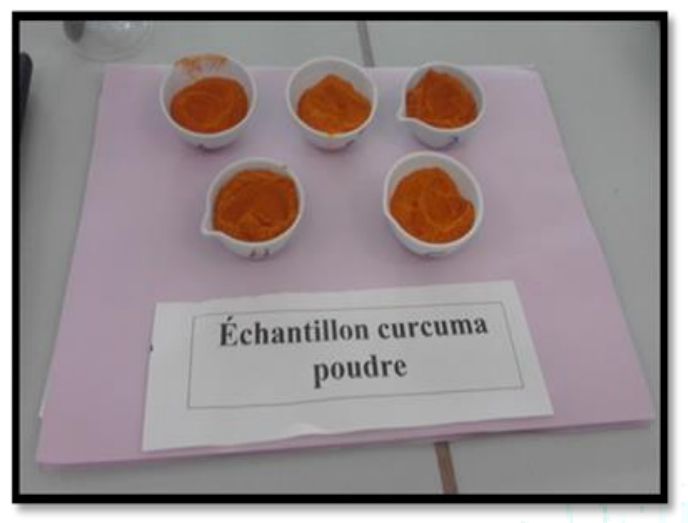

Figure 1: Curcuma longa (powder).

For this study, we selected 5 spice stores randomly located in the town of Sétif, (Fig.03). The different analyses of the studied physicochemical parameters were carried out in two different laboratories such as: the INSEP laboratory (national specialized institute of vocational training Hadi cherif El Hiddab Sétif) and the ERIAD laboratory (Riad Sétif). The data

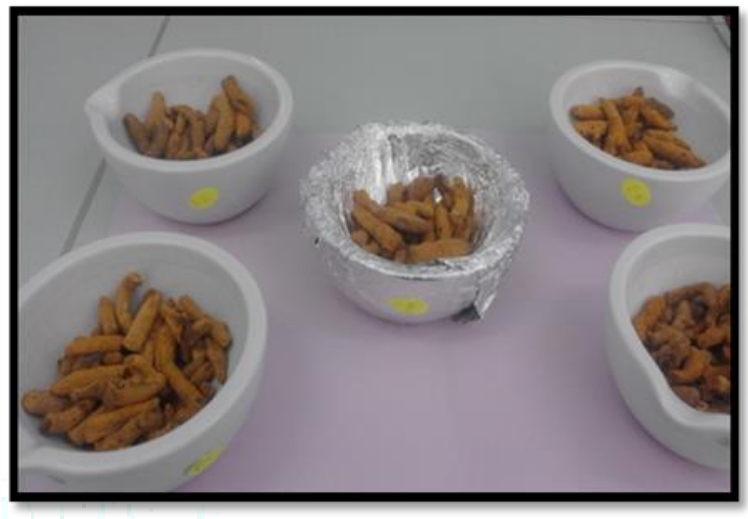

Figure 2: Curcuma longa (rhizome)

collected were statistically processed using the "Costat" software for an analysis of variance and a comparison of means between the different samples. The results obtained are also referred to the standards of the French official journal 1.

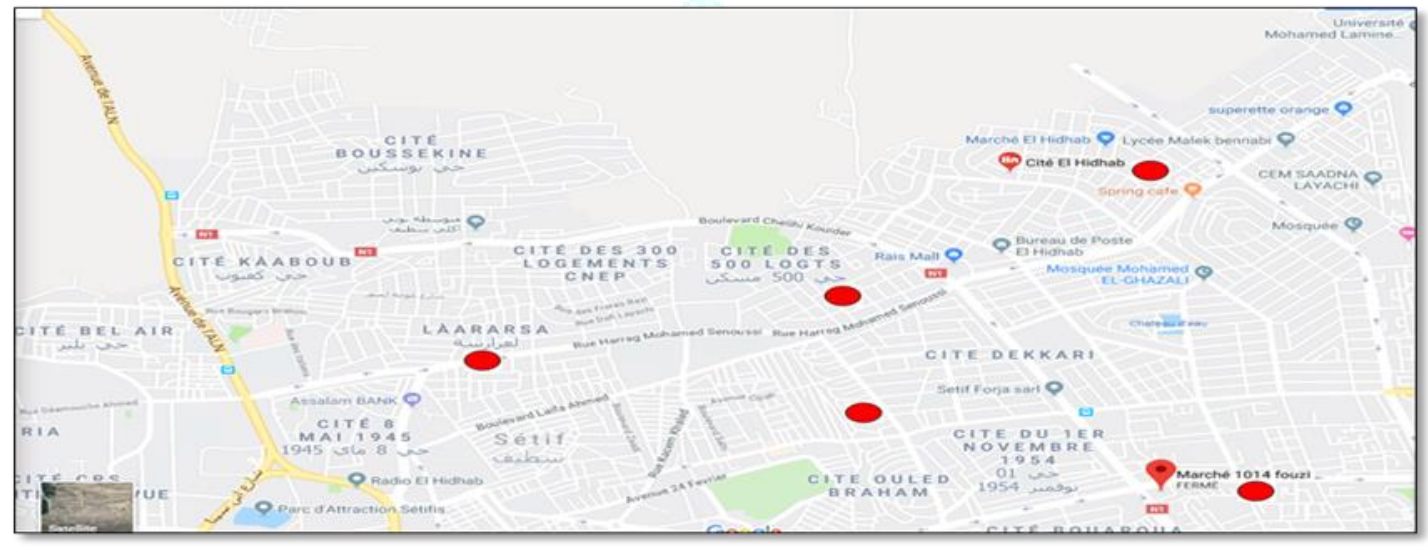

Figure 3: Location of the study sites in the town of Sétif

\section{Analyses of the various physico-chemical parameters Impurity rate (NF - V03-402 1982).}

The quantification of impurities consists of separation by sieving. A test sample of approximately 30 grams is sieved through a sieve with a diameter of $355 \mu \mathrm{m}$ (Fig.04). The retentate is considered as impurities.

The level of impurities, in percent by mass, is calculated by the following formula:

\section{TImp (\%) $=(\mathrm{PImp} \times 100) / \mathrm{PPE}$}

Where: * TImp (\%): Impurity content, expressed as a percentage by mass.

*PImp: Weight of impurities in grams.

*PPE: Weight of test portion in grams 


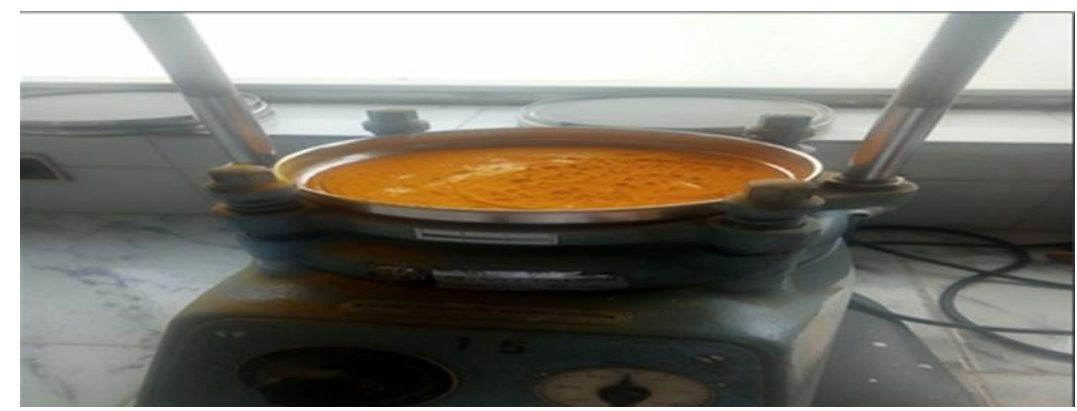

Figure 4: Sieving of Curcuma longa (powder form)

\section{Determination of water content (NF V 03402; 1982)}

It is the sudden loss of mass of the product after heating at $115^{\circ} \mathrm{C}$ for $2-3$ hours, it is expressed in \% mass (Fig.05 and 06).

The water content, expressed in \% mass, is given by the following formula:

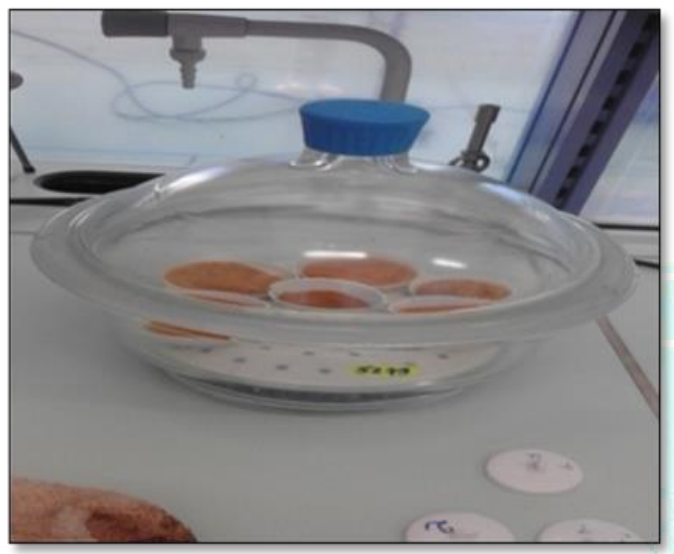

Figure 5: Sample in the Desiccator

\section{Determination of total ash on dry matter}

Total ash expression is a term referring to the inorganic portion of a food sample remaining after the sample (Fig.07 and 08 ) has been burned at $800^{\circ} \mathrm{C}$ for two hours. Carried out according to the method $\mathbf{1 3}$.

The total ash content, expressed as a percentage, is given by the following equation:

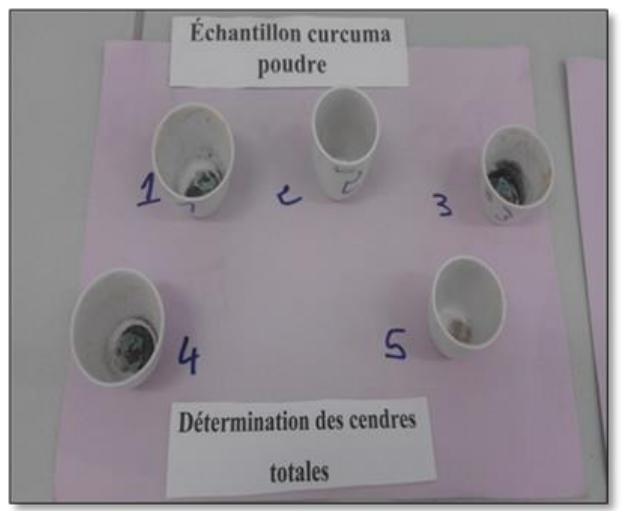

Figure 7: Curcuma carbonization

\section{Water content $(\%)=(\mathrm{p0}-\mathrm{p} 1) \times 100 / \mathrm{p} 0$}

Where *p0 $(=\mathrm{m} 1-\mathrm{m} 0)$ : mass, in grams, of the test sample before drying.

*p1 (= m2-m0): mass, in grams, of the test sample after drying.

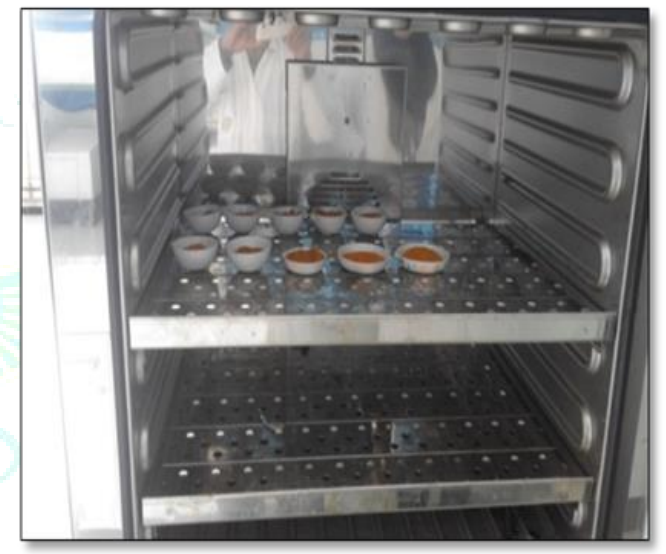

Figure 6: Baking of samples (Powder and rhizome)

WTA $(\%)=[(m 3-m 1) /(m 2-m 1)] * 100$

Where:

- WTA: total ash content, expressed as percentage by mass.

${ }^{*}$ m1: mass, in grams, of the empty capsule.

${ }^{*} \mathrm{~m} 2$ : mass, in grams, of the capsule and the test sample.

${ }^{*} \mathrm{~m} 3$ : mass, in grams, of the capsule and the residue obtained.

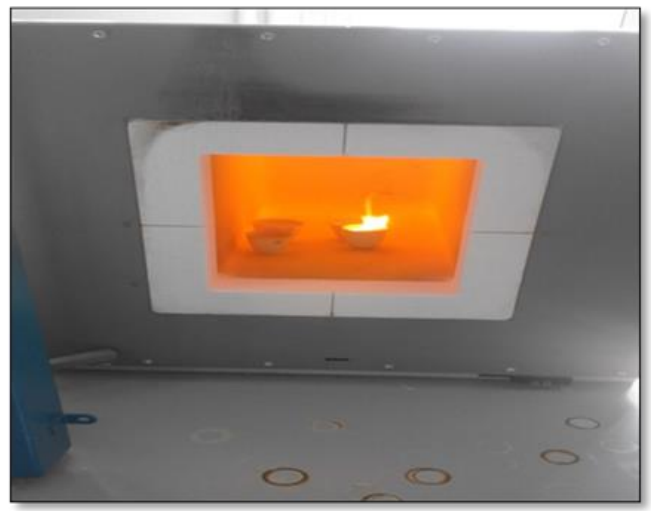

Figure 8: Carbonization of Curcuma in muffle furnace 


\section{Determination of acid-insoluble ash in dry matter}

Acid insoluble ash is defined as the proportion of total ash remaining after treatment with hydrochloric acid and heating of the sample (Fig.09) until constant weighing according to the protocol (NF V 03-405; 1982),

The insoluble ash content, expressed as a percentage, is given by the following relationship:

$$
\text { WA }(\%)=[(m 3-m 1) /(m 2-m 1)] * 100
$$

WA: total ash content, expressed as percentage by mass.

* m1: mass, in grams, of the empty capsule.

*m2: mass, in grams, of the capsule and the test sample.

*m3: mass, in grams, of the capsule and the residue obtained.

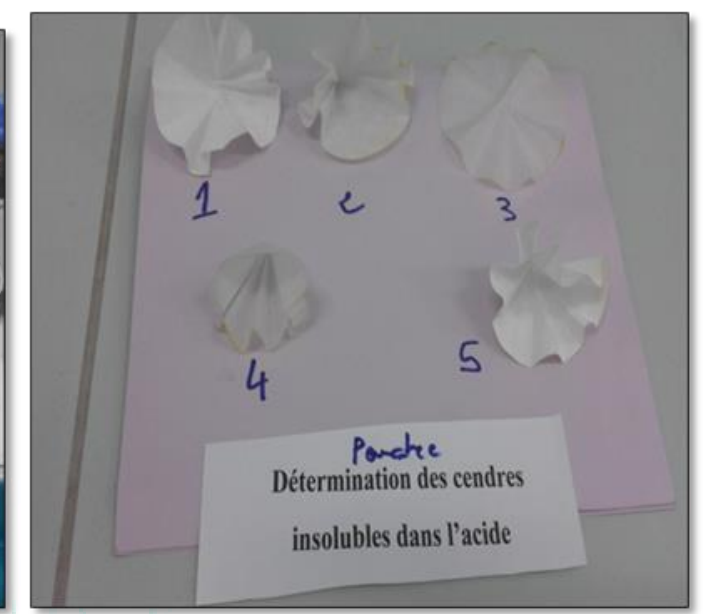

Figure 9: Filtration of acid-insoluble ashes

\section{Determination of water-soluble ashes}

Treatment of the total ash obtained according to (NF V 03405 ; 1982), with boiling water for 5 minutes with $25 \mathrm{ml}$ of water (Fig.10 and 11).

The insoluble ash content, expressed as a percentage, is given by the following relationship:

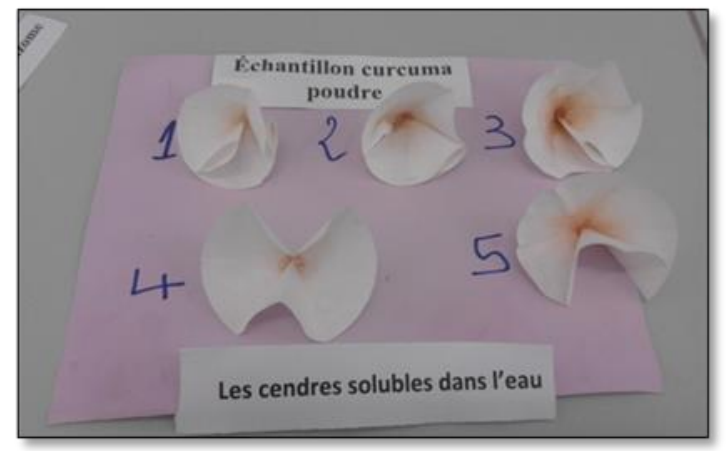

Figure 10: Filtration of water-soluble ash (Curcuma powder)

\section{Determination of the tinting strength of Curcuma (NF V 32-156,1982)}

The extraction of the pigments from Turmeric is carried out using hot ethanol. The dilution of the extract is measured by absorbance spectrophotometry at the wavelength of the absorption maximum at $425 \mathrm{~nm}$ (Figs. 12 and 13).

$$
\frac{\mathrm{A} \times \mathrm{D} \times 100}{\mathrm{E}_{\mathrm{jom}} \mathrm{is} \times \mathrm{m}}-\frac{\mathrm{A} \times 50 \times 100}{1607 \times \mathrm{m}}
$$

\section{WA $(\%)=[(m 3-m 1) /(m 2-m 1)] * 100$}

-WA : teneur en cendres totales, exprimée en pourcentage en masse.

•m1 : masse, en grammes, de la capsule vide.

-m2 : masse, en grammes, de la capsule et de la prise d'essai. -m3 : masse, en grammes, de la capsule et du résidu obtenu.

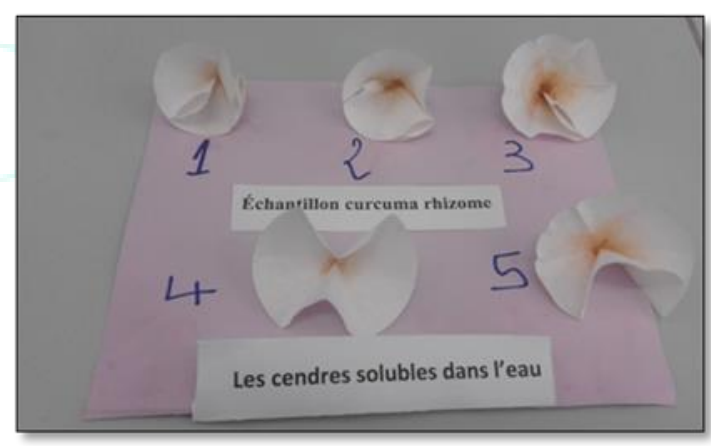

Figure11: Filtration of water-soluble ash (Curcuma rhizome after grinding)

\section{A: measured absorbance \\ D: dilution of extract}

$\mathrm{E}^{1} \%$ is the specific absorbance of a $1 \%$ solution of Curcuma, measured at $425 \mathrm{~nm}$ in cuvettes with an optical path length of $1 \mathrm{~cm}$, i.e. 1607.

$\mathrm{m}$ : mass, in grams, of the test sample. 


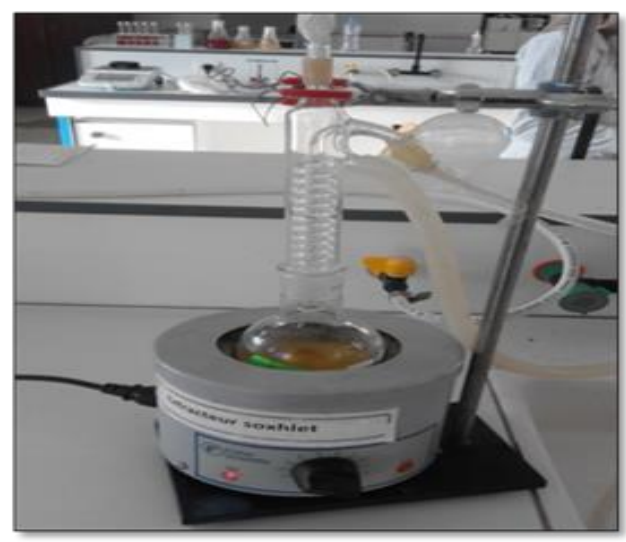

Figure 12: Soxhlet extractor

Separation of different coloured pigments by thin-layer chromatography

The pigments extracted from Turmeric were separated by TLC.

\section{Preparation of the tank}

The vessel atmosphere must be saturated with eluent vapor. The eluent has been poured over a height of $1 / 2 \mathrm{~cm}$.

- Eluent: -Petroleum Ether/Ethyl Acetate: (7-3)

\section{Preparation of the chromatographic plate}

-Take a silica-gel plate.

-Using a pencil, draw a line $1.5 \mathrm{~cm}$ from the bottom edge of the plate.

-Lightly mark with a pencil on this line, the locations where the extracts to be analysed will be deposited. The locations should be about $1 \mathrm{~cm}$ apart and $1 \mathrm{~cm}$ from the edges of the plate. (Fig 14)

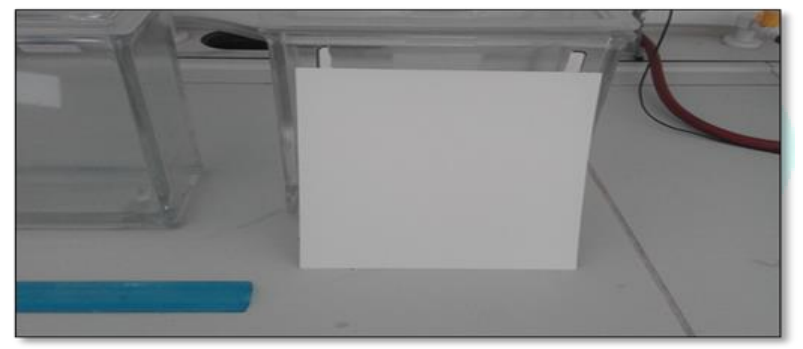

Figure 14 : Chromatography Paper (TLC)

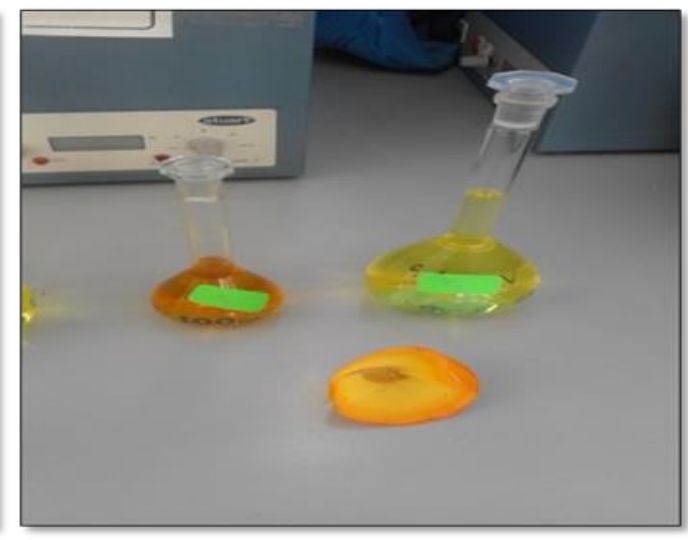

Figure 13: Dilution of the extract with ethanol

\section{Depositing the sample}

-Using a propette, take a small drop of Turmeric extract and place it in the marked place.

-Make several deposits in the same place, leaving to dry between each deposit (Fig. 15).

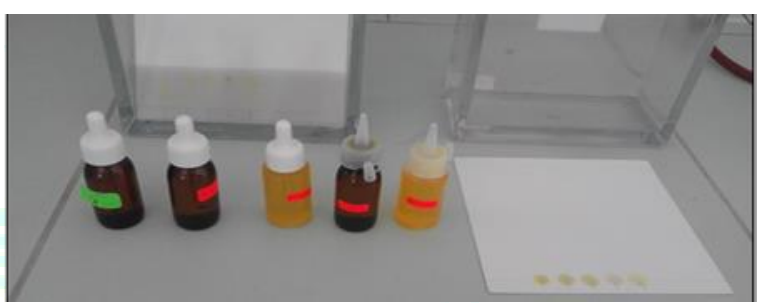

Figure 15: Deposition of dyestuff extracts at TLC.

\section{Élution}

-When the deposits are dry, insert the plate vertically into the cell (the deposit line must not dip into the eluent) and close.

-During elution, the eluent migrates onto the plate by impregnating the silica.

-Remove the plate from the cell at the end of elution.

-Use a pencil to mark the solvent front with a pencil, using the eye and UV light to mark the spots.

\section{Revelation (chromatogram development)}

Observe the chromatogram and circle with a pencil the different coloured spots that appear (Fig. 16).
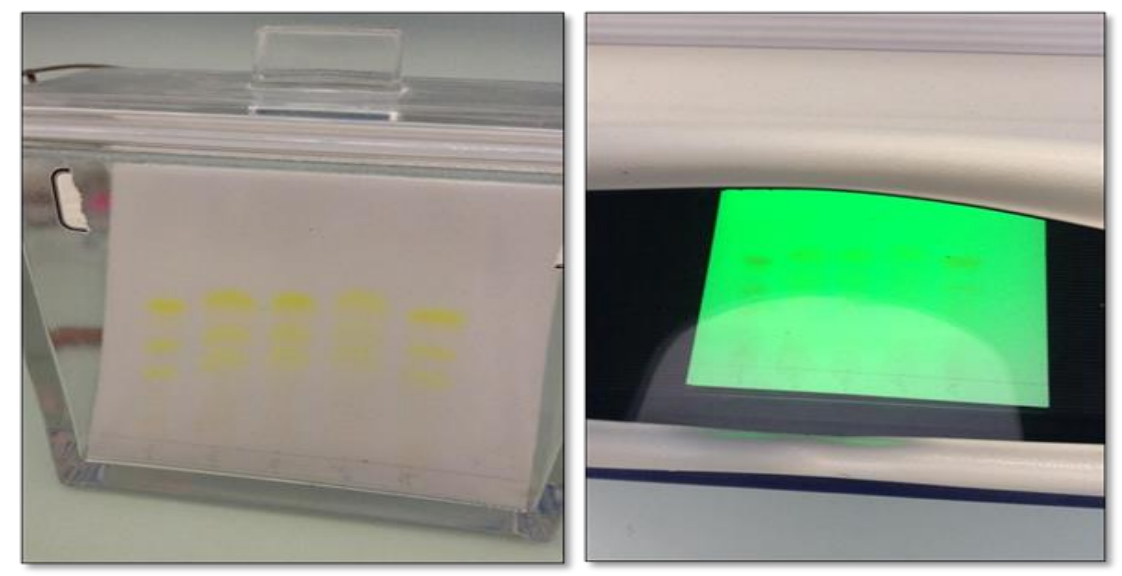

Figure 16: UV Chromatogram Spot Revelation 


\section{Calculation of Frontal Ratio (Rf)}

For each spot we calculated the retention factor, which is equal to the distance travelled by the constituent divided by the distance travelled by the solvent.

$$
\mathbf{R f}=\mathbf{d} / \mathbf{D}
$$

$\mathrm{d}$ : Distance travelled by the constituent

D: Distance travelled by the eluent's edge

This factor is characteristic of a substance taking into account the solvent used.

\section{RESULTS}

\section{Impurity rate}

The impurity content of turmeric shows variations of the order of 4,9\% for the powder and 3,9\% for the rhizome. Indeed, the highest levels for the type (Curcuma powder) were observed in store 5 with an average of about $12.3 \%$ (Fig. 17), while store 4 has a lower impurity level of $7.4 \%$. For the rhizome, the levels of impurities in stores 2, 3 and 5 are almost equal, with averages of $8.6 \%$ and $8.5 \%$ respectively, while the lowest average is found in store 1.

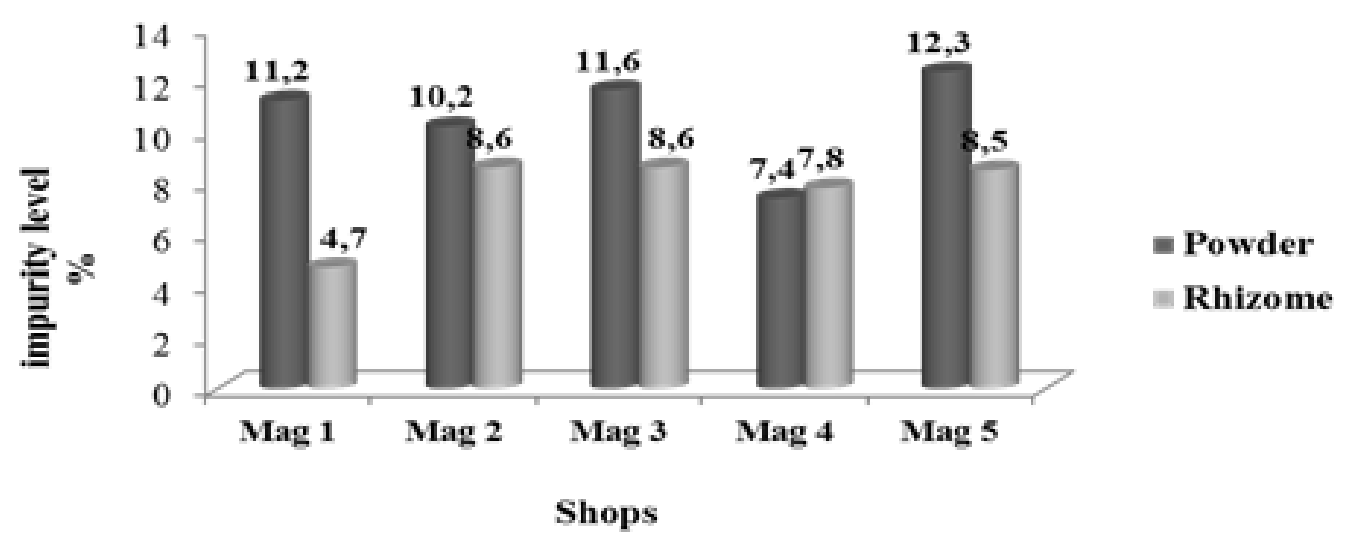

Figure 17: The \% content of impurities in Curcuma longa (powder and rhizome) sold in different shops.

Analysis of the variance of impurities in the two types of samples (powder and rhizomes) shows a highly significant difference (Table 1). The classification of dockage is done according to two homogeneous groups; the first group (A) which corresponds to the rhizome type with an average of $0.5 \%$ where the samples contain more dockage and group (B) corresponds to the powder dockage with a low average of $0.27 \%$ where the samples have less dockage compared to the rhizome type.
Table 1, also shows the analysis of variance between different samples in the same type both in the powder and in the rhizome. For the powder factor, the analysis of variance is highly significant between samples (stores), where it shows two homogeneous groups; group (A) includes stores 1 and 5 with high averages in the order of $13.8 \%$ and $13.6 \%$ respectively, it has a higher dockage than the other stores. Group (B) is represented by store 4 with an average of $7.83 \%$ where the latter has a low dockage level.

Table 1: Analysis of variance of impurities for both types (Rhizome and powder) and between samples of each type.

\begin{tabular}{|c|c|c|c|c|}
\hline Type & Mean & $\mathrm{P}<0,05$ & Samples & $P<0,05$ \\
\hline \multirow[t]{5}{*}{ Powder } & \multirow[t]{5}{*}{$0.272 \mathrm{~b}$} & \multirow[t]{10}{*}{$0.0012^{* * *}$} & 13,8 & \multirow[t]{5}{*}{0.013 ** } \\
\hline & & & $11,8 \quad a b$ & \\
\hline & & & $12,03 \mathrm{ab}$ & \\
\hline & & & $7,83 \quad b$ & \\
\hline & & & 13,6 & \\
\hline \multirow[t]{5}{*}{ Rhizome } & \multirow[t]{5}{*}{$0.544 \mathrm{a}$} & & $6,63 \quad a$ & \multirow[t]{5}{*}{$0,602 \mathrm{NS}$} \\
\hline & & & 10,66 a & \\
\hline & & & $11,6 \quad a$ & \\
\hline & & & 11,06 a & \\
\hline & & & 10,86 a & \\
\hline
\end{tabular}

a, b, c: significant difference at the $5 \%$ threshold. (NS= not significant) 


\section{Humidity level}

According to Fig. 18, the moisture content of Curcuma longa is variable between the two types of the species (powder and rhizome) and between stores. Turmeric in rhizome form has higher values than turmeric powder, where the highest moisture content of around $13.4 \%$ is recorded at store 3 , while stores $1,2,4,5$ have very similar values, with the lowest $12.5 \%$ recorded by store 1 . On the other hand, Turmeric powder has lower rates between $10.5 \%$ and $11.7 \%$, with the highest value recorded in store 5 and the lowest in stores 3 and 4.

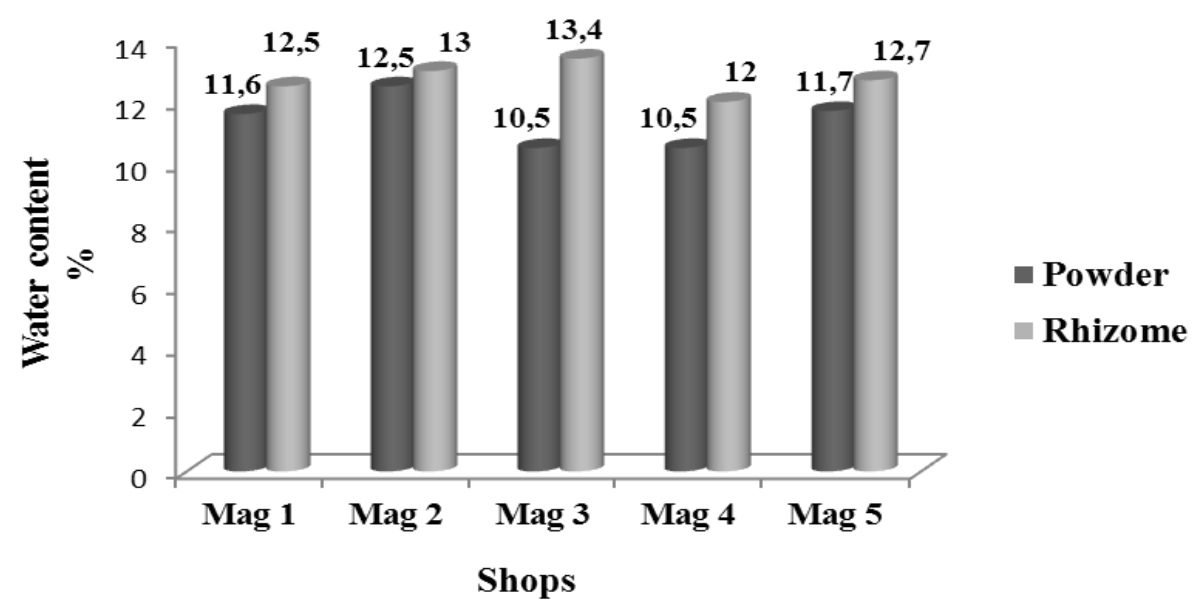

Figure 18: Moisture content in \% of Curcuma powder and rhizome sold in different shops.

The results of the analysis of variance of the water content, or moisture content, of Turmeric are highly significant both for the type of Turmeric and for different stores within the same type.

The average of turmeric in Rhizome is higher; it is about $12.92 \%$, against a lower rate of $11.36 \%$ for turmeric powder (Table 2).

Analysis of variance for both factors shows the existence of different homogeneous groups. For the rhizome factor, there are three different homogeneous groups, such as group A with a high average of $13.43 \%$ represented by store 3 , group $\mathrm{B}$ represented by stores 2 and 4 with respective averages of 13.00 and $13.06 \%$. On the other hand, group $\mathrm{C}$ is represented by stores 1 and 5 with lower averages of $12.70 \%$ and $12.53 \%$. For the powder factor, there are also three different homogeneous groups, such as group A with a high average of $12.5 \%$ represented by store 2 , group $B$ represented by stores 1 and 5 with averages of $11.63 \%$ and $11.76 \%$ respectively. On the other hand, group $\mathrm{C}$ is represented by stores 3 and 4 with lower averages of $10.53 \%$ and $10.56 \%$.

Table 2: Results of the analysis of variance for moisture content

\begin{tabular}{|c|c|c|c|c|}
\hline Type & Mean & $\mathrm{P}<0,05$ & Samples & $\mathrm{P}<0,05$ \\
\hline \multirow[t]{5}{*}{ Powder } & \multirow[t]{5}{*}{$11.36 \mathrm{a}$} & \multirow[t]{10}{*}{$0,0054 * * *$} & $11,63 \mathrm{~b}$ & \multirow[t]{5}{*}{$0,0000^{* * *}$} \\
\hline & & & 12,50 a & \\
\hline & & & $10,53 \mathrm{c}$ & \\
\hline & & & $10,56 \mathrm{c}$ & \\
\hline & & & $11,76 \mathrm{~b}$ & \\
\hline \multirow[t]{5}{*}{ Rhizome } & \multirow[t]{5}{*}{$12.92 \mathrm{~b}$} & & $12,53 \mathrm{c}$ & \multirow[t]{5}{*}{0,0002 *** } \\
\hline & & & $13,00 \mathrm{~b}$ & \\
\hline & & & 13,43 a & \\
\hline & & & $13,06 \mathrm{~b}$ & \\
\hline & & & $12,70 \mathrm{c}$ & \\
\hline
\end{tabular}

a, b, c: significant difference at the $5 \%$ threshold.

\section{Total ash content}

From Fig 19, we notice for the rhizome factor, the highest contents are recorded at the level of stores 4, 5, 2 and 1 with averages of around $5.6 \% \quad 5.16 \%$ and $5.3 \%$ and $5 \%$ respectively. While store 3 has the lowest ash content with an average of $4.3 \%$.
At the same level of Figure 19, it can be seen that the collected powder shows variations of the order of $3.7 \%$ and with lower contents in relation to the rhizome factor except for store 4, which records a higher total ash content with a value of $5.8 \%$. Whereas, store 2 recorded the lowest value with $2.1 \%$ ash content. 


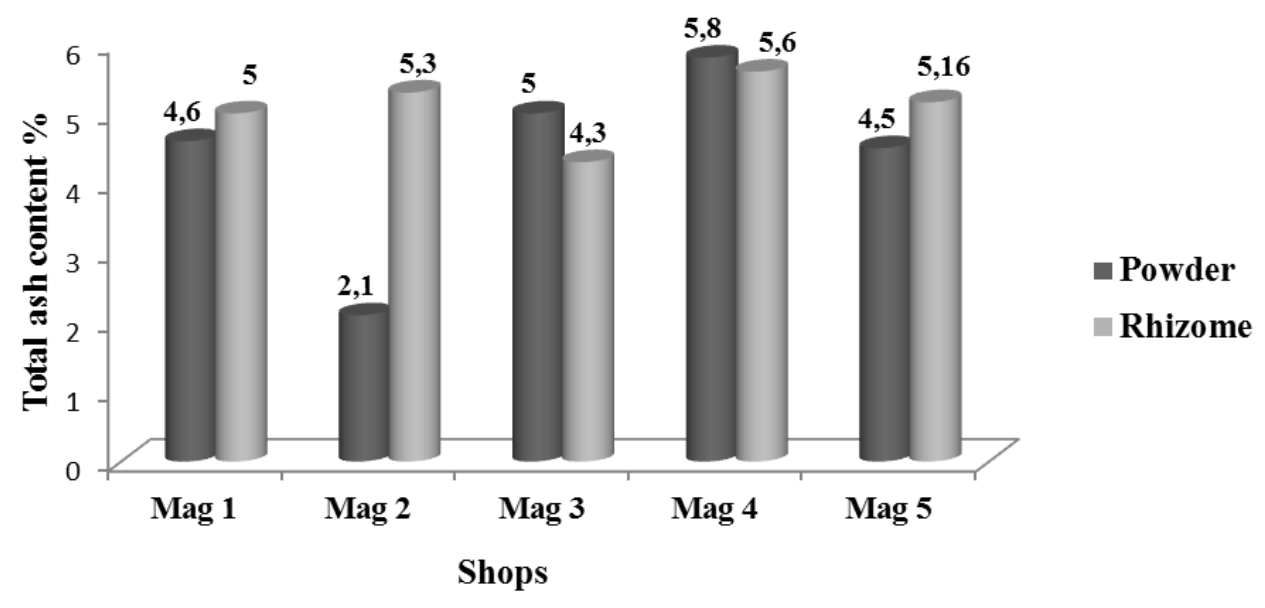

Figure 19: Total ash content in \% of Turmeric powder and rhizome in the different stores.

The results in Table 3 , show that the total ash content of Turmeric a non-significant difference between the two factors powder and rhizome with respective averages of
$5.06 \%$ for the rhizome and $4.04 \%$ for the powder. It is also non-significant between stores.

Table 3: Results of analysis of variance of total ash content

\begin{tabular}{|c|c|c|c|c|}
\hline Type & Mean & $\mathrm{P}<0,05$ & Samples & $\mathrm{P}<0,05$ \\
\hline \multirow[t]{5}{*}{ Powder } & \multirow[t]{5}{*}{$4.40 \mathrm{a}$} & \multirow{10}{*}{$0,3434 \mathrm{NS}$} & $4,66 a$ & \multirow{5}{*}{$0,5476 \mathrm{NS}$} \\
\hline & & & 3,66 a & \\
\hline & & & 5,00 a & \\
\hline & & & $5,83 a$ & \\
\hline & & & $4,50 a$ & \\
\hline \multirow[t]{5}{*}{ Rhizome } & \multirow[t]{5}{*}{$5.06 \mathrm{a}$} & & $5,00 \mathrm{a}$ & \multirow{5}{*}{$0,8291 \mathrm{NS}$} \\
\hline & & & 5,33 a & \\
\hline & & & $4,33 \mathrm{a}$ & \\
\hline & & & 5,66 a & \\
\hline & & & 5,16 a & \\
\hline
\end{tabular}

a, b, c: significant difference at the $5 \%$ threshold (NS= not significant)

\section{Acid-insoluble ash content}

The highest values of insoluble ash were recorded at the rhizome level with high averages for all stores $1,2,3,4.5$ with rates (between $0.42 \%-0.52 \%$ ) compared to the marketed powder which recorded lower values with averages of $0.38-0.37 \%$ for stores $2,3.4$ and $0.04 \%$ for stores 1 and 5 (Fig20).

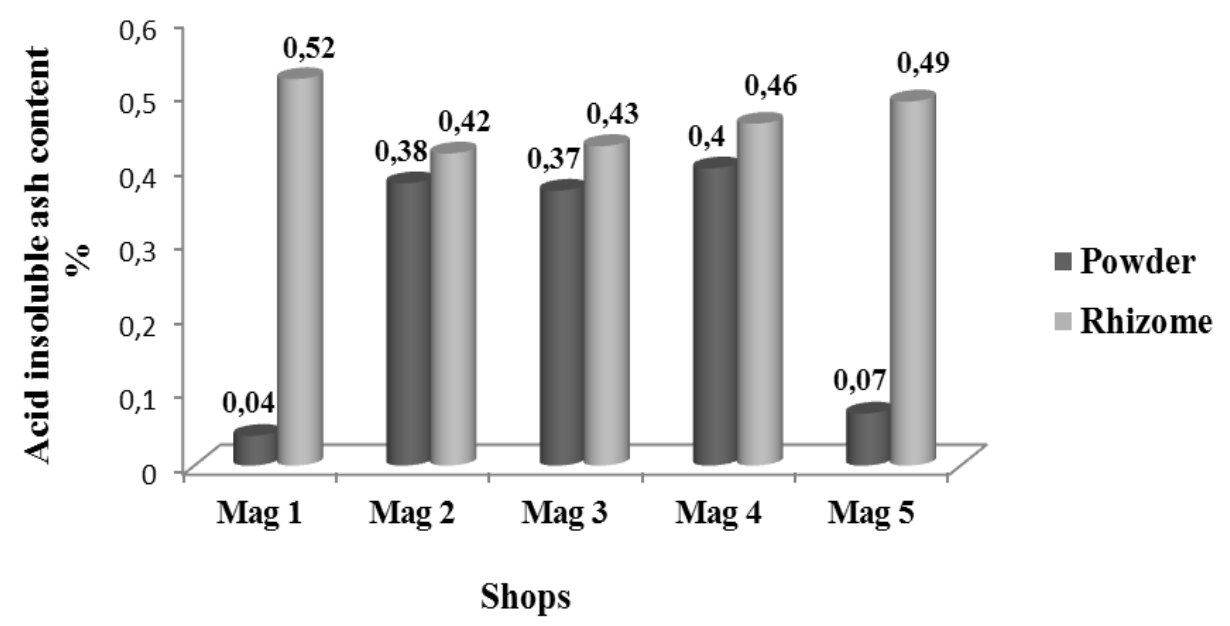

Figure 20: The \% content of the acid-insoluble ash of Curcuma sold in different shops. 
The analysis of variance of acid insoluble ash content shows a significant difference between the two factors powder and rhizome with respective averages of about $45.8 \%$ and
$24,00 \%$ while it is non-significant between the different samples (Table 4).

Table 4: Results of analysis of variance of acid insoluble ash content

\begin{tabular}{|c|c|c|c|c|}
\hline Type & Mean & $\mathrm{P}<0,05$ & Samples & $\mathrm{P}<0,05$ \\
\hline \multirow[t]{5}{*}{ Powder } & \multirow[t]{5}{*}{$24,00 \mathrm{~b}$} & \multirow{10}{*}{$0,0311 *$} & $4,00 \mathrm{a}$ & \multirow{5}{*}{$0,2442 \mathrm{NS}$} \\
\hline & & & $4,00 \mathrm{a}$ & \\
\hline & & & $3,00 \mathrm{a}$ & \\
\hline & & & $3,66 \mathrm{a}$ & \\
\hline & & & $4,33 \mathrm{a}$ & \\
\hline \multirow[t]{5}{*}{ Rhizome } & \multirow[t]{5}{*}{$45.80 \mathrm{a}$} & & 0,52 a & \multirow{5}{*}{$0,9989 \mathrm{NS}$} \\
\hline & & & $0,42 a$ & \\
\hline & & & 0,42 a & \\
\hline & & & 0,46 a & \\
\hline & & & 0,46 a & \\
\hline
\end{tabular}

a, b, c: significant difference at the $5 \%$ threshold (NS= not significant)

\section{Water-soluble ash content}

The powder registers maximum soluble ash contents (Fig.21) between 8.3\% -2.6\% compared to the rhizome factor values which show low levels of around 5\% - 2.3\%.

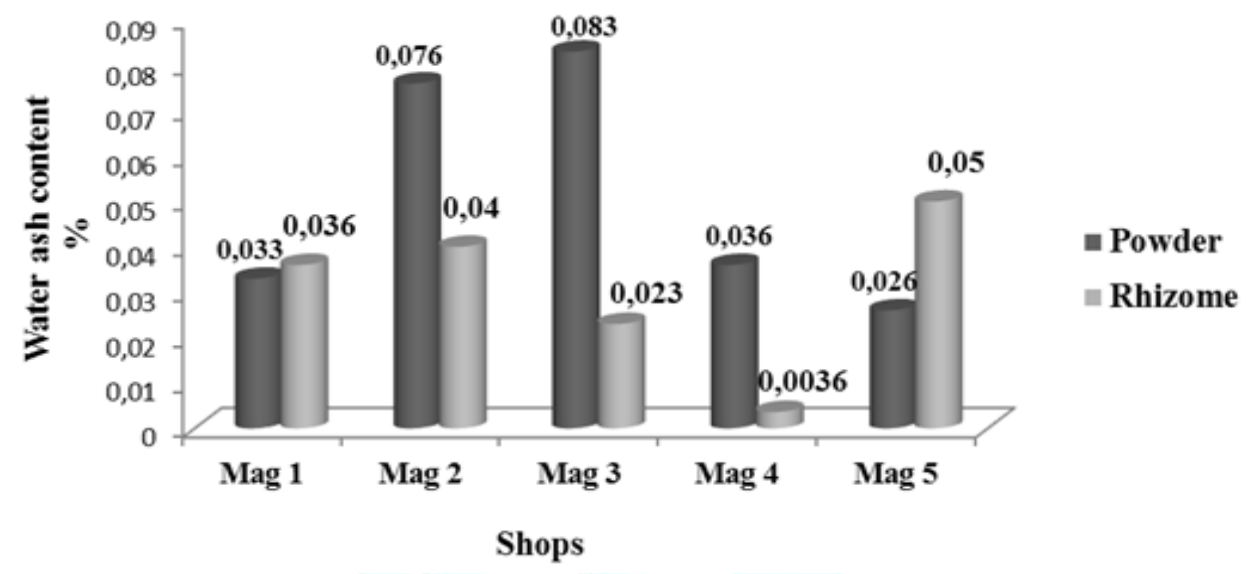

Figure 21: The \% content of water-soluble ash in Curcuma in different stores

The results of the water soluble ash contents recorded show a non-significant difference between the two factors rhizome and powder with averages of $5.08 \%$ for powder and $3.70 \%$ for rhizome. It is also non-significant between the different samples (stores) of the two types of Turmeric (Table 5).

Table 5: Results of the analysis of the variance of the water-soluble ash content between turmeric types and between different samples.

\begin{tabular}{|c|c|c|c|c|}
\hline Type & Mean & P0,05 & Samples & P0,05 \\
\hline \multirow[t]{5}{*}{ Powder } & \multirow[t]{5}{*}{$5.08 \mathrm{a}$} & \multirow[t]{10}{*}{$0,3070 \mathrm{NS}$} & $3,00 \mathrm{a}$ & \multirow[t]{5}{*}{$0,5452 \mathrm{NS}$} \\
\hline & & & 5,60 a & \\
\hline & & & 5,30 a & \\
\hline & & & $2,00 \mathrm{a}$ & \\
\hline & & & $1,16 a$ & \\
\hline \multirow[t]{5}{*}{ Rhizome } & \multirow[t]{5}{*}{$3.70 \mathrm{a}$} & & $3,66 \mathrm{a}$ & \multirow[t]{5}{*}{$0,7555 \mathrm{NS}$} \\
\hline & & & $3,00 \mathrm{a}$ & \\
\hline & & & $4,00 \mathrm{a}$ & \\
\hline & & & $2,83 \mathrm{a}$ & \\
\hline & & & 2,16 a & \\
\hline
\end{tabular}

a, b, c: significant difference at the $5 \%$ threshold (NS= not significant) 


\section{Coloring power of Curcuma}

According to Fig 22, the optical density recorded by the powder type is the highest where the highest values are recorded at magazine 2 with an optical density of about $3.19 \%$, while magazine 5 shows a lower optical density with $0.9 \%$.

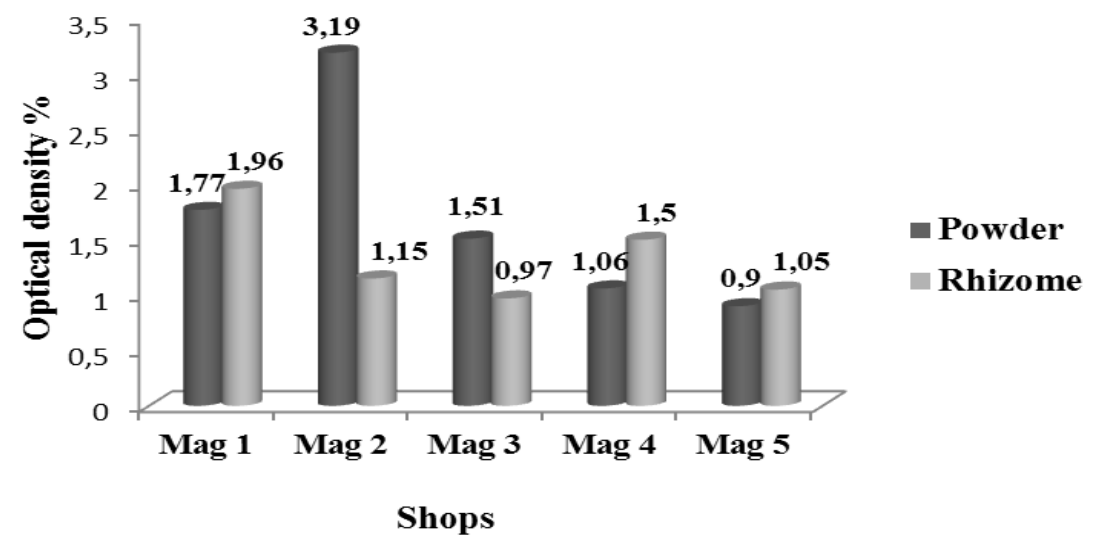

Figure 22: Optical density (\%) between types of Curcuma and between different stores.

The results of the density of the curcumonoid extract (Table 6) show that the analysis of variance is non-significant between factors (rhizome and powder) with means $1.602 \%$ for the powder and $1.32 \%$ for the rhizome. It is also nonsignificant between samples.

Table 6: Results of the analysis of variance of the optical density

\begin{tabular}{|c|c|c|c|c|}
\hline Type & Mean & $\mathrm{P}<0,05$ & Samples & $\mathrm{P}<0,05$ \\
\hline \multirow{5}{*}{ Powder } & \multirow{5}{*}{$1.602 \mathrm{a}$} & \multirow{10}{*}{0,4825 NS } & 1,77 a & \multirow{5}{*}{ 0,5298 NS } \\
\hline & & & 2,77 a & \\
\hline & & & $1,51 \mathrm{a}$ & \\
\hline & & & 1,06 a & \\
\hline & & & $0,90 \mathrm{a}$ & \\
\hline \multirow[t]{5}{*}{ Rhizome } & \multirow[t]{5}{*}{$1.324 \mathrm{a}$} & & $1,96 \mathrm{a}$ & \multirow[t]{5}{*}{$0,3538 \mathrm{NS}$} \\
\hline & & & 1,15 a & \\
\hline & & & 0,97 a & \\
\hline & & & 1,49 a & \\
\hline & & & $1,05 \mathrm{a}$ & \\
\hline
\end{tabular}

a, b, c: significant difference at the $5 \%$ threshold (NS= not significant)

\section{Thin layer chromatography of dyestuffs}

The TLC results of the extracts of the different samples, revealed the presence of three spots or spots corresponding to the different components of the extract of Curcuma powder and rhizome. (Fig 23).
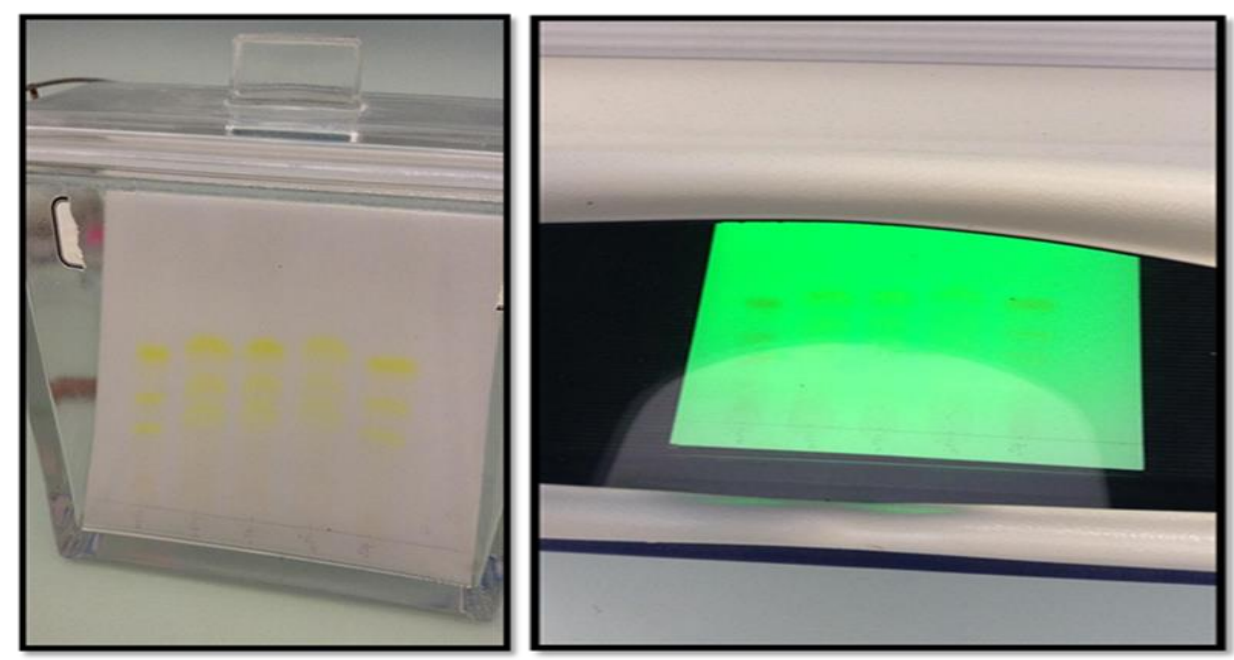

Figure 23: TLC results for Curcuma extracts 
Indeed, these different tasks correspond to the different frontal Rf reports, namely:

- Rf $1=$ corresponds to BDMC = bisdemethoxycurcumin...
- Rf 2 = corresponds to DMC = demethoxycurcumin

- $\operatorname{Rf} 3$ = corresponds to $\mathrm{C}=$ curcumin

Table 7: Frontal ratio of the different spots found on the TLC plate of Curcuma longa extracts

\begin{tabular}{|c|c|c|c|c|c|}
\hline Tyре & Mean & $\mathrm{P}<0,05$ & Samples & $\begin{array}{l}\text { Norms } \\
\text { (Supamattaya } \\
\text { and } a l, .2005 \text { ) }\end{array}$ & $P<0,05$ \\
\hline Powder & 0,52 b & 更 & \begin{tabular}{|c|}
0,32 \\
0,33 \\
0 \\
0,38 \\
0 \\
0,39 \\
\end{tabular} & 0,70 & 0,775 NS \\
\hline Rhizome & 0,66 a & $0,000^{* * *}$ & $\begin{array}{c}0,65 \text { a } \\
0,67 \text { a } \\
0,66 \text { a } \\
0,68 \text { a } \\
0,68 \text { a }\end{array}$ & & $0,114 \mathrm{NS}$ \\
\hline
\end{tabular}

a, b, c: significant difference at the $5 \%$ threshold (NS= not significant)

The results of the analysis of variance of the TLC (Table 7) represented by the Rf3 corresponding to the essential component of Curcuma longa named curcumin calculated from the longest distance travelled by this component according to the reference $\mathbf{1 6}$. For this, the analysis showed that there is a highly significant difference between the two types of Turmeric (powder and rhizome), while the difference between the different samples for both types is not significant.

\section{DISCUSSION}

In this work, some parameters indicative of the physicochemical quality of Curcuma longa (turmeric powder and rhizome turmeric) and between the samples marketed in some shops in the town of Setif, were studied, the results show:

Calculated impurity levels revealed relatively low values for both types (rhizome and powder) compared to standards which should not exceed $10 \pm 2 \% 1$. The analysis of variance between these two types is highly significant $\left(\mathrm{P}=0.0012^{* * *}\right)$. On the other hand, the impurity levels for the rhizome with an average of $0.544 \%$ are higher than the powder level by $0.272 \%$, as well as for the different samples where the rhizome samples have higher impurity levels than the powder. This explains why the rhizome contains more impurities than the commercial powder since the latter is more protected in plastic bags, in addition to the source of grinding at the samples is different for the two types compared to the rhizome which is more exposed to various impurities.

The determination of moisture content shows that both types of Turmeric have $12.92 \%$ for the rhizome and $11.36 \%$ for the powder; these contents are slightly higher than the standards 1 . These levels seem to be influenced by the conservation of Turmeric. Indeed a too strong moisture induces a bad conservation of spices by facilitating the appearance of moulds and by supporting the bacterial development.

Determination of the total ash content makes it possible to control the load of spices in various mineral products $\mathbf{1 4}$. It helps to detect inferior quality products, depleted products and excess mineral matter. Indeed, the analysis of the total ash contents determined is not significant between the two types of turmeric, where the rhizome registers a $5.06 \%$ higher content than the $4.04 \%$. Since these two contents do not fall within the standards provided by $\mathbf{1}$ which are in the range of $7-9 \%$, we can deduce that these two types are of inferior quality containing less minerals.

The determination of acid-insoluble ashes gives an idea of the quality and purity of their total inorganic content 7 . Our results for acid-insoluble ash (Rhizome and powder) of Turmeric show a non-significant difference between the two types. The ash content of the rhizome was $0.45 \%$ and the powder $0.24 \%$. These contents are lower than the standards set by 1 , which is about $1.5 \%$. This explains why our samples are of better quality, free of inorganic compounds. While the comparison between types; the powder seems to be of better quality than the rhizome.

The tinting strength of the two types of Turmeric determined by measuring the absorbance of an alcoholic extract at 425 $\mathrm{nm}$ by spectrophotometry indicated that the analysis is significant between the two types of Turmeric. The results of the optical densities obtained recorded contents of the order of $1.60 \%$ for the powder and $1.32 \%$ for the rhizome, which explains why the powder contains more curcumin than the rhizome.

*Thin layer chromatographic analysis showed the separation of the content of 3 components: curcuminoids or curcumin (c) from demethoxycurcumin (DMC), bisdemethoxycurcumin (BDMC).curcumin actually refers to a set of yellow colouring matters called curcuminoids or curcumin. Curcuminoids is the non-volatile fraction consisting of pigmentary principles, 
curcuminoids about $5-8 \%$ 1. The TLC of curcuma dyes studied revealed three tasks corresponding to the different components of Curcuma. Our results show that the analysis between the two types of Turmeric is highly significant and that the Rf3 is 0.52 for the powder lower than that of the rhizome which is 0.66 . This is because the rhizome contains more curcumin and substituents than the powder which contains less curcumin.

\section{CONCLUSION}

At the end of this work, the objective was to determine certain physicochemical quality parameters of the Curcuma longa species in its two forms (rhizome and powder). The parameters studied are those quoted by the French official journal. We can say that our results are more or less satisfactory:

For the levels of impurities, total ash, ash insoluble in acid and water, coloring power and chromatography (TLC) are in accordance with the standards indicated by AFNOR, $1982^{1}$. But the problem arises at the level of the parameter moisture content which does not enter the standards which explains that there is a problem of conservation of the samples.

Between the two types (rhizome and powder) studied we can say that the rhizome is the part of the plant that should be used much more as a daily culinary spice, given its composition very rich in a major compound which is curcumin compared to the powder. At the end of this study, we can conclude that the quality control of spices is a very neglected area in Algeria compared to other foodstuffs. This requires a very strict monitoring and control especially in the city of Sétif, since these products are very much used in the culinary field with the great risk it can generate on human health in the long term and as very promising preservatives for the food industry.

\section{REFERENCES}

[1] AFNOR 1982. Recueil des normes françaises. Contrôle de la qualité des produits alimentaires, épices et aromates.

[2] Bruneton. J. 1999. Pharmacognasy: Phytochemistry of Medicinal Plant. Lavoisier Techniques and Documentation.

[3] Burt S. Essential oils: their antibacterial properties and potential applications in foods: a review. International Journal of Food Microbiology 2004; 94:223-253.
[4[ Calvo Ana M., Wilson R, A., Woo Bok J., and. Keller NP. Relationship between Secondary Metabolism and Fungal Development. Microbiol Mol Biol Rev. 2002; 66(3):447-459.

[5] Chahardehi A.M., Ibrahim D., Sulaiman S.F. 2010. Antioxidant, antimicrobial activity and toxicity test of pileamicrophylla. International Journal of Microbiology, Article ID 826830. p 6.

[6] Guiraut J. P. Microbiologie alimentaire. Ed. DUNOD, Paris. 2003 ; p 110-112.

[7] Hombourger C. 2010. Le Curcuma, de l'épice au médicament. Thèse diplôme d'Etat de Docteur en Pharmacie. Université henripoincararé, Nancy I .Faculté de pharmacie.P222.

[8] Ho C.L., Wang E.I.C., Su Y.C. Essential oil compositions and bioactivities of the various parts of Cinnamomum camphora Sieb. var. linaloolifera Fujuta. 2009 ; p. 77-96.

[9] Kim K.M., Pae H.-O., Zhung M., Ha H.-Y., Ha Y.A., Chai K.-Y. Involvement of anti-inflammatory heme oxygenase- 1 in the inhibitory effect of curcumin on the expression of proinflammatory inducible nitric oxide synthetase in RAW 264.7 macrophages. Biomed. Pharmacother., 2008; 62(91):630 - 636.

[10] Ma W. G., Tan R. X., Fuzzati N., Li Q. S., Wolfender J. L., Hostettmann K. Natural occurring and synthetic polyyne glycosides. Phytochemistry, 1997; 45(2):411-45.

[11] Nessrien M.N.Y., Mohamed A.T. Antioxidant and antimicrobial effects of marjoram and thyme in coated refrigerated semi fried mullet fish fillets. World J. Dairy \& Food Sci., 2007; 2(1) :01-09.

[12] Pascal G. Les antioxygènes alimentaires, Cahier de Nutrition et de Diététique, 1979; 14 :271-290.

[13] Priyanka R., Vasundhara M., Jayaram A., Nuthan D. A study on curcuminoid profile of Curcuma longa L. varieties as affected by processing method. International Journal of Phamaceutical Sciences, 2016; 2(2):56-59.

[14] Rouzet M., Touche J.. Les normes dans le contrôle de la qualité des épices et aromates. In : Richard H., Epices et aromates Technique et Documentation, Lavoisier, Paris. 1992; 240-247.

[15] Rozier J., Carlier V., Bolno, F. . Bases microbiologiques de l'hygiène des aliments. É d. SAPALC. Paris. 1986; p 130-143.

[16] Supamattaya K., Suntornchareonnon N., Boonyaratpalin M., Klowkliang T. Effects of Thai medicinal plants on pathogenic bacterial, growth performance, health condition and disease resistance in black tiger shrimp (Penaeus monodon Fabricius). Songklanakarin J. Sci. Technol., 2005; 27(Suppl. 1):55-70 